\title{
PENGAJARAN BAHASA INGGRIS UNTUK ANAK USIA DINI BEBERAPA HAL YANG HARUS DIPERHATIKAN
}

\author{
Zobi Mazhabi1, \\ 1,2 Universitas Islam Malang \\ e-mail: ${ }^{1}$ zobi.mazhabi@unisma.ac.id
}

Diterima: 27 November 2019 I Direvisi: 31 Desember 2019 I Disetujui: 31 Desember 2019 (C)2019 Pendidikan Guru Raudhatul Atfhal Fakultas Agama Islam Universitas Islam Malang

\begin{abstract}
The need, awareness, and understanding about the early foreign languages teaching on young learners makes the education experts try to apply English learning and teaching as early as possible for students. Therefore, English has been introduced in formal educational institutions at the level of early childhood. This decision made experts have to consider several things in term of learning and teaching English as a foreign language (EFL) and early childhood as students when a foreign language is introduced and taught at the level of early childhood (young learners), then an understanding of how foreign language acquisition or second language on children (SLA) and learning and teaching foreign languages (Teaching English as Foreign Language / TEFL) in children needs to be understood and considered as a reference for conducting the learning process, so that good and appropriate learning methods can be formulated. In this article, the author tries to elaborate on the process of language acquisition in children (language acquisition), both in their first language (L1) and their second language (L2), as well as how an understanding of these can have a positive interfearence on the formulation and selection of the right method. in the process of learning and teaching English at the level of early childhoo.
\end{abstract}

Keywords: First Language Acquisiton, (L1), Foreign Language Acquisition (L2), Teaching and Learning English for Young Learner.

\section{A. Pendahuluan}

Pada abad ini, penggunanan Bahasa Inggris semakin memasuki semua lini dalam kehidupan baik pada ranah formal dan informal seperti bidang pendidikan, perdagangan, dan komunikasi. Bahasa Inggris ini juga telah mendominasi sebagai alat komunikasi diseluruh dunia pada era revolusi industri 4.0 ini. Sehingga para lembaga pendidikan berlomba-lomba menyelenggarakan pembelajaran dan pengajaran Bahasa Inggris di berbagai level pendidikan formal, non formal, level pendidikan tinggi, level pendidikan menegah, dan lebih lebih pendidikan pada

This work is licensed under Creative Commons Attribution Non Commercial 4.0 International License Available online on: http://riset.unisma.ac.id/index.php/fai/index 
level anak usia dini. Melihat animo ini, Para pakar pendidikan anak usia dini juga merespon dengan sangat masif fenomena yang terjadi ini yaitu dengan memberlakukan pembelajaran dan pengajaran Bahasa Inggris pada level anak usia dini atau PAUD (English for young learners/EYL). Keputusan ini di ambil melihat posisi bahasa Inggris sebagai sebuah bahasa pengantar dunia yang di pakai sebagai media komunikasi utama dalam segala bidang pergaulan sebagaimana di jelaskan oleh Jenifer Jeanskin (2001:11) English has been used internationally as the lingua franca of the world (Bahasa Inggris telah digunakan secara internasional sebagai sebuah bahasa pergaulan dunia).

Kesadaran akan urgensinya penguasaan bahasa Inggris (English Mastery) pada peserta didik melahirkan tantangan dan masalah tersendiri bagi para pakar dan pendidik untuk mendesain metode pembelajaran Bahasa Inggris yang efektif dan menyenangkan bagi anak usia dini (young learner). Sebagai bahasa asing (foreign language), bahasa Inggris merupakan hal yang baru bagi anak-anak, terutama sekelompok anak yang tidak menggunakan Bahasa Inggris pada lingkungan keluarganya atau yang jarang bersinggungan dengan bahasa Inggris (english mileu). Terlebih lagi, di Negara Indonesia Bahasa Inggris merupakan bahasa asing yang tidak dipergunakan sebagai bahasa percakapan sehari hari. Hal ini membuat para orang tua, khususnya para guru, berasumsi bahwa anak-anak akan sangat kesulitan untuk mengikuti pembelajaran bahasa Inggris, sehingga pembelajaran yang dilakukan jauh dari harapan bersifat students centered dan cenderung menyuapi serta mencekoki peserta didik dengan materi materi Bahasa Inggris. Hal ini terjadi karena para pendidik memposisikan diri mereka sebagai pelajar Bahasa Inggris sehingga teknik, metode, dan strategi belajar yang digunakan merefleksikan bagaimana cara yang pernah dilakukan oleh guru tersebut. padahal beberapa hasil penelitian dan pemerhati pendidikan anak usia dini seperti Devinta, Iswahyuni, dkk ( 2018:9) menjelaskan bahwa perkembangan pembelajaran bahasa pada anak usia dini diklasifikasikan menjadi beberapa kategori , kategori pertama pada usia 4 thaun sampai 6 tahun dimana mereka sudah mampu mendengarkan, berkomunikasi, dan memiliki perbendaharaan kosakata yang lebih banyak.

Kategori yang kedua adalah usia 3-6 tahun dimana mereka belajar berbahasa dengan berkomunikasi dan mendengarkan serta mengenal kosakata dalam objek-objek yang konkrit yang dekat dengan lingkungan mereka, dan belum mengenal tata bahasa dikarenakan para pelajar dalam fase ini berada pada level pendidikan PAUD atau disebut juga very young learners. Sedangkan pada usia 7-9 tahun, merka disebut young learners karena mereka sudah berada pada level pendidikan kelas 1-3 sekolah Dasar. Anak-anak pada fase ini mulai membaca, 
menyusun kalimat dan telah memiliki perbendaharaan kosakata yang bersifat konkrit dekat dengan lingkungan mereka. Adapun pada fase terakhir atau late young learners mereka berusia 10-12 tahun. Mereka telah mampu membaca, berkomunikasi mendengarkan, memiliki perbendaharaan kosakata konkrit dan memahami tata Bahasa Inggris yang bersifat induktif.

Melalui tulisan ini, penulis bertujuan untuk mendeskripsikan bagaimana peroses pembelajaran Bahasa Inggris berbasis pada pemerolehan Bahasa pertama (L1/first language) serta menjelaskan perbedaan antara pembelajaran, pengajaran Bahasa dan pemerolehan Bahasa. Disamping itu, Pada artikel ini, penulis membahas dan mengkaji beberapa kasus dan permaslahan yang sering salah dipahami oleh para pengajar Bahasa Inggris di level pendidikan anak usia dini dengan rumusan masalah sebagai berikut : a. Seperti apa proses pembelajaran dan pengajaran (teaching and learning) dan pemerolehan (acquiring) Bahasa asing pada anak ? b. bagaimanakah cara merancang metode pengajaran dan pembelajaran (teaching and learning) Bahasa asing pada anak berdasarkan pada cara belajar dan pemerolehan (acquiring) Bahasa yang terjadi pada anak?

\section{B. Metode}

Metode penelitian dalam penelitian ini mengunakan studi pustaka atau library research. Penelitian dilakukan dengan cara mengumpulkan berbagai sumber dan literasi terkait dengan topik bahasan yang dibahas oleh peneliti, dari berbagai sumber yang berbentuk bacaan dan video guna di telaah untuk menyelesaikan permasalahan yang terdapat pada penelitian. Pada penelitan ini Teknik pengumpulan data yang dilakukan meliputi beberapa langkah berikut: 1) pengumpulan sumber-sumber terkait topik yang dibahas seperti buku, buku digital, jurnal terkait, laporan, video, dan kurikulum Pembelajaran Bahasa Inggris untuk anak usia dini, 2) melakukan peroses pengumpulan data dengan mempelajari referensi yang sudah terkumpul melalui proses pemahaman, penelaahan, sintesis, dan penyimpulan. 3) memasukkan kerangka teori atau simpulan yang dihasilkan kedalam sub topik yang sesuai dengan sub topik yang terformulasikan dalam penelitian.

\section{Hasil dan Pembahasan}

1. Pemerolehan Bahasa

Terminologi pemerolehan bahasa merupakan terminologi yang sering digunakan pada studi pemerolehan bahasa kedua (second language acquisition/SLA) dimana istilah pembelajaran dan pengajaran sangatlah berbeda dengan pemerolehan bahasa (language acquisition). Istilah bahasa pada kontek ini 
menurut penjelasan Barbara (1982:5) language is our life. It always exists and used in the academical life and outside the classroom, it also gives the basic need for the individual to socialize in social context. Bahasa merupakan bagian dari kehidupan kita. bahasa selalu exsis dan digunakan dalam berbagai kontek seperti kontek akademik dan kebutuhan komunikasi di luar kelas, Bahasa juga menjadi kebutuhan dasar bagi seorang individu untuk bersosialisasi pada kontek kehidupan sosial. Ellis (1995:14) mengutip Krashen mendifinisikan pemerolehan Bahasa sebagai “... subconscious process of picking up language through exposure and the later to the conscious process of studying it." Pemerolehan Bahasa adalah peroses yang terjadi pada alam bawah sadar manusia seperti ketika mengakuisisi Bahasa pertama, tidak seperti belajar merupakan peroses yang terjadi dalam keadan sadar dan dikondiskan untuk belajar. Selain itu, Sigel dan Cocking (2000: 5) juga menjelaskan bahwa pemerolehan bahasa merupakan sebuah proses dimana anak-anak mengadaptasi sejumlah hipotesis dengan ucapan atau bahasa orang tua sampai dapat memilih kaidah tata bahasa yang baik dan sederhana dari bahasa yang digunakan oleh orang tua yang bersangkutan dan Bahasa yang sering dipergunakan dilingkungan di mana seorang anak itu dilahirkan. Sejumlah hipotesis yang dirumuskan oleh anak dalam fase ini akan tumbuh berkembang sesuai dengan variasi interaksi anak dalam berbagai konteks dengan lawan bicaranya (interlucator) dan kemudian diuji berulang-ulang untuk mendapatkan pengetahuan bagaimana bahasa itu diucapkan, digunakan dan dimainkan dalam konteks komunikasi.

Berdasarkan beberapa pandangan dan kajian para ahli di atas, dapat disimpulkan bahwa pemerolehan Bahasa merupakan peroses alamiah alam bawa sadar manusia dalam mengenali simbol- simbo, lambang-lambang, dan sandi-sandi dari lingkungan sekitarnya, berupa kumpulan bunyi-bunyi, ucapan-ucapan (uterences) yang selanjutnya akan dikembangkan dan digunakan sebagai sebuah sistem komunikasi dengan orang lain di lingkungan sekitarnya sesuai dengan perkembangan otak anak yang bersangkutan. Dalam proses ini, anak menangkap, mengenali, mengidentifikasi dan mengkategorikan secara alami seluruh kata, tuturan, ataupun ekspresi dari lingkungan sekitarnya tanpa peroses pengondisian oleh orang lain atau orang tuanya. Rujukan dasar yang digunakan oleh seorang anak dalam proses pemerolehan bahasa ini antara lain adalah konteks, bahasa tubuh (verbal language) ataupun nada dari bunyi-bunyi yang mereka tangkap dan dengarkan dari lawan bicaranya (interlucator) yang selalu mengajak mereka berbicara, terutama orang-orang terdekat dalam keluarganya dan lingkungan bermainnya, yang kemudian mereka identifikasi dan mereka gunakan sebagai sebuah cara untuk berkomunikasi. 


\section{Pemerolehan Bahasa Pertama}

Proses pemerolehan bahasa pertama pada seorang anak terjadi secara alamiah atau dalam keadaan alam bawah sadar manusia. Seorang anak dalam melakukan pemerolehan bahasa di mulai dari mendengarkan dan menangkap kemudian mengenali simbol- simbol dari lingkungannya, yaitu berupa bunyi-bunyi (ucapan) dan ragam bahasa yang selanjutnya terus dikembangkan dan digunakan sebagai sistem berkomunikasi dengan orang sekitarnya sesuai dengan perkembangan otak seorang anak. Dalam proses ini, anak menangkap, mengenali, mengidentifikasi dan mengkategorikan secara alami seluruh kata, ragam bahasa, ataupun ekspresi dari apa yang didapatkan di lingkungan sekitarnya. Dasar paling utama yang dipergunakan dalam proses pemerolehan bahasa oleh seorang anak adalah konteks, bahasa tubuh (verbal language), kumpulan bunyi-bunyi, dan ragam bahasa yang mereka akuisisi, yang kemudian mereka identifikasi dan mereka gunakan sebagai sebuah cara untuk berkomunikasi dalam kesehariannya. Oleh karena itu, dapat disimpulkan bahwa seorang anak pertama kali melakukan pemerolehan bahasa pada saat pertama kali mendegar satuan bunyi, ragam bahasa, dan ujaran-ujaran dari lingkungan sekitarnya.

Pada dasarnya bayi pada usia baru lahir yakni usia satu tahun disebut dengan istilah infant atau tidak mampu berbicara. Ketidakmampuan berbicara ini bukan berarti ketidak mampuan untuk berkomunikasi karena walaupun tanpa bahasa bayi telah berkomunikasi dengan orang yang memeliharanya dalam bentuk tangisan, senyuman, dan gerak-gerak tubuh. Hal ini terjadi karena tahap perkembangan bahasa seorang bayi (kanak-kanak) menurut Madyati (2016:54) dapat terbagi dalam dua tahapan, tahapan pertama tahap perkembangan artikulasi yang meliputi bunyi resonansi, bunyi berdekut, bunyi berleter, bunyi berleter ulang, bunyi vokabel atau suku kata ke kata, dan tahapan kedua adalah tahapan perkembangan kata dan kalimat yang memiliki variasi yang lebih kompleks daripada fase pertama karena merupakan perkembangan dari kemampuan vokabel menuju kemampuan untuk mengucapkan kata pertama, kalimat satu kata dan kalimat dua kata. Dan semua tahap perkembangan ini berawal dari kemampuan para bayi mendengarkan bunyi, ujaran hingga kata dan kalimat dari lingkungan sekitarnya lebih lebih orang yang mengasuh dan memeliharanya.

Berdasarkan pemaparan diatas manusia pada daarnya memiliki kemampuan bahasa dan berbahasa yang bersifat bawaan atau innate capacity yang dapat berkembang sesuai dengan perkembangan kapasitas keilmuan dan kematangan intlektual seorang individu. Hal ini senada dengan apa yang di jelaskan oleh para kaum mentalis atau navistik Chomsky (2006:15) bahwa faktor lingkungan bukan merupakan faktor yang teramat penting bagi seorang anak 
dalam belajar Bahasa karena pada dasarnya setiap manusia atau anak telah dibekali dengan alat yang memungkinkan mereka untuk memiliki kemampuan berbahasa yang cepat dan mudah semenjak dilahirkan, alat ini dinamakan struktur bahasa universal pada otak manusia atau Language Acquisition Device yang menunjukan manusia terlahir telah dipersiapakan untuk berbahasa.

Menurut Chomsky (1959: 15) Kelengkapan bahasa pada manusia ini terdiri dari beberapa hipotesis bawaan yaitu suatu pola tingkah laku yang bersifat khusus dari persepesi kecakapan mengkategorikan dan mekanisme relasi bahasa, secara biologis telah ditemuakan. Lebih jelas lagi Mc Neill dalam Brown, 1980, p.22 telah menyebutkan bahwa Language Acquisition Device (LAD) pada otak manusia terdiri dari beberapa hal: kemampuan membedakan bunyi bahasa dengan bunyi yang lain, kemampuan mengkelompokkan suatu rumpun linguistik kedalam sejumlah kelompok yang akan dapat berkembang pada kemudian hari, dan pemahaman atau ilmu tentang konsep bahasa yang bersifat mungkin dan mustahil, serta kemampuan dalam pengunaan konsep bahasa yang berdasarkan pada evaluasi perkembangan sistem linguistik.

Disamping itu, Chomsky 1959 dalam Otto 2015, p. 34 memberikan argumentasi yang lebih detail terkait Language Acquisition Device (LAD) yang di analogikan sebagai sebuah "kotak hitam kecil" pada otak manusia ini memiliki saat-saat kritis atau critical period, yaitu ketika seorang anak berada pada usia 0-6 tahun. Pada masa kritis ini, seorang anak mampu menerima informasi dalam jumlah yang banyak dan tak terbatas sehingga memungkinkan mereka untuk menyerap bahasa dengan cepat dan mudah bahkan mereka akan mampu memperoleh dua atau tiga bahasa yang berbeda dalam satu masa yang bersamaan.

Pada pandangan yang lain, Teori Behavioristik menjelaskan bahwa bahasa dapat dikuasi dan diperoleh melalui peroses pembiasaan mendengarkan dan mengucapkan. Menurut Abdul Chaer (2003: 222) dalam kacamata behavioristik peroses pemerolehan bahasa dipengaruhi dan dikendalikan oleh factor yang berasal dari lingkungan sekitar anak. Dengan kata lain, kemampuan berbicara dan memahami sebuah bahasa diperoleh melalui stimulus dari lingkungannya dimana seorang anak berposisi sebagai penerima pasif dari tekanan yang uncul dari lingkungannya, tidak memiliki peranan yang aktif di dalam proses perkembangan perilaku verbalnya. Proses perkembangan bahasa terutama ditentukan oleh lamanya latihan yang diberikan oleh lingkungannya.

Dengan demikian, proses pemerolehan bahasa pada anak berlangsung dan berkembang secara baik dengan adanya piranti lunak bawaan atau Language Acquisition Device (LAD) yang kemudian diaktifkan dengan adanya data- data atu informasi-informasi berupa paparan terhadap bahasa yang didapatkan dari 
lingkungannya seperti bunyi-bunyi yang dimulai dari satuan bunyi yang paling sederhana hingga paling kompleks, dan kemudian dikembangkan secara mandiri (autonomous) dan alami (natural) melalui rangsangan dan respon lawan bicara sebagai upaya anak membangun interaksi dengan lingkungannya. Fase pengembangan bahasa inilah yang selanjutnya dapat diarahkan kepada pembelajaran bahasa.

\section{Pemerolehan Bahasa VS Pembelajaran Bahasa}

Istilah pemerolehan bahasa biasanya dibedakan dengan istilah pembelajaran bahasa. Istilah pembelajaran bahasa digunakan berkaitan dengan proses yang terjadi pada waktu seorang anak mempelajari bahasa kedua setelah dia memperoleh bahasa pertamanya. Dengan kata lain, pemerolehan bahasa berkenaan dengan bahasa pertama, sedangkan pembelajaran bahasa berkenaan dengan bahasa kedua (Chaer, 2003, p.167). Walaupun istilah yang digunakan adalah pemerolehan bahasa kedua, namun istilah itu meliputi segala proses pembelajaran bahasa apapun setelah bahasa pertama, baik itu bahasa kedua, ketiga, keempat dan seterusnya. Oleh karena itu, bahasa lain selain bahasa pertama disebut bahasa kedua atau juga disebut sebagai bahasa target untuk membedakan antara bahasa kedua dan bahasa asing, The Collins Dictionary (2013) mendefinisikan bahasa kedua sebagai bahasa yang dipelajari setelah bahasa ibu nya dan bahasa asing sebagai bahasa yang digunakan di negara selain negara asalnya.

Perbedaan utama dari pemerolehan bahasa pertama dan kedua atau asing adalah pada setting proses belajarnya. Pemerolehan bahasa pertama dilakukan secara alami dan tidak sadar, sedangkan pemerolehan bahasa kedua dilakukan secara sadar dan formal. Oleh sebab itu, proses yang terjadi dalam "kepala" anak pun diduga akan berbeda. Dari beberapa teori mengenai pemerolehan bahasa, maka dapat dirumuskan perbedaan-perbedaan proses dalam pemerolehan bahasa dan pembelajaran bahasa. Berikut ini adalah perbedaan-perbedaan dalam proses pemerolehan dan pembelajaran.

Tabel 1. Distingsi Proses Pembelajaran dan Proses Pemerolehan Bahasa

\begin{tabular}{|l|l|}
\hline \multicolumn{1}{|c|}{ Pembelajaran } & \multicolumn{1}{|c|}{ Pemerolehan } \\
\hline $\begin{array}{l}\text { a. Proses yang tidak disadari } \\
\text { b. Mengalami }\end{array}$ & a. Proses yang disadari \\
c. Mendapatkan sumbernya & b. Mengingat \\
& c. Mendapatkan sumbernya \\
dari komunikasi alami & dari pengetahuan yang \\
disadari
\end{tabular}




\begin{tabular}{|l|ll|}
\hline $\begin{array}{l}\text { yang benar dan mana yang } \\
\text { salah }\end{array}$ & $\begin{array}{l}\text { dari orang lain mengenai } \\
\text { apa yang benar dan apa } \\
\text { yang salah }\end{array}$ \\
e. Hasilnya difokuskan kepada & e. $\begin{array}{l}\text { Hasilnya difokuskan kepada } \\
\text { bentuk }\end{array}$ \\
makna & f. Kesalahan masih diterima & $\begin{array}{l}\text { Kesalahan dianggap sebagai } \\
\text { sebuah kegagalan }\end{array}$ \\
\hline
\end{tabular}

Proses pemerolehan bahasa yang bersifat alami dilihat sebagai sebuah proses yang memiliki efek jangka panjang dalam hal penguasaan konsep-konsep dasar berbahasa, karena berbasis pengujian hipotesis secara mandiri dari pengalaman. Namun, dalam proses pengembangannya perlu juga dilakukan rangsangan- rangsangan yang dirancang secara sengaja untuk memaksimalkan tingkat perkembangannya. Oleh karena itu, pengetahuan mengenai proses pemerolehan bahasapada anak dapat menjadi dasar dari perumusan metode pembelajaran bahasa Inggris untuk anak yang efektif, karena dengan mengadaptasi kepada proses alami pemerolehan bahasa, hasil pembelajaran yang didapatkan diharapkan dapat memiliki efek berkelanjutan dan berjangka panjang sebagai bekal untuk proses pengembangannya bahasa Inggris sebagai bahasa asing selanjutnya

\section{Pembelajaran Bahasa Inggris Pada Anak Usia Dini}

Seperti yang telah dibahas sebelumnya, bahwa pembelajaran bahasa Inggris yang dilakukan sedini mungkin merupakan langkah yang tepat. Stakanova dan Tolsikhina (2014) juga menambahkan mengenai tepatnya mengajarkan bahasa inggris pada anak usia dini dengan menyatakan beberapa alasan sebagai berikut:

a. Pada periode ini perkembangan linguistik anak sedang dalam tahap yang sangat baik untuk digunakan sebagai dasar dalam perkembangan linguistik selanjutnya.

b. Sebuah permulaan yang dilakukan lebih awal menyediakan waktu belajar yang lebih maksimal bagi pembelajaran bahasa inggris sebagai bahasa asing - semakin cepat memulai maka semakin banyak waktu untuk belajar

c. Anak yang belajar bahasa asing pertamanya di pra-sekolah atau tingkat sekolah dasar memiliki kesempatan yang lebih baik untuk mempelajari bahasaasing kedua di sekolah menengah.

d. Belajar bahasa asing di usia dini merangsang kemampuan anak untuk menggunakan bahasa ibunya dengan lebih baik.

Namun, seperti yang telah diutarakan dalam sub-bab sebelumnya, perlu diperhatikan bahwa anak memiliki cara belajar yang berbeda dengan orang tua. Maka, sebaiknya dalam perumusan metode pembelajaran, pengetahuan mengenai 
keunikan dan karakteristik pembelajaran bahasa pada anak perlu diketahui terbih dahulu.

Dari hasil penelitiannya, O'grady (2007) merumuskan setidaknya ada 5 karakteristik dasar dalam cara seorang anak belajar bahasa, yaitu:

a. Anak-anak memulai pelajaran bahasanya dengan mendengarkan. Mendengarkan adalah kekuatan utama mereka dalam 'meramu' aspekaspek dalam bahasa. Bagi anak, bahasa adalah bunyi yang memiliki fungsi dan makna. Interaksinya dengan lingkungan, membantunya memahami konteks dan makna.

b. Anak mempelajari bahasa dengan sangat cepat. Hanya dengan mendengarnya satu atau dua kali mereka dapat menangkap referen sebuah bunyi untuk sebuah benda atau makna. Bahasa tubuh dan intonasi atau penekanantertentu pada kata merupakan bantuan yang sangat besar bagi anak memahami bahasa. Dengan kata lain, awalaupun kekuatan anak dalam belajara berbahasa adalah mendengarkan, seorang anak tidak dapat belajar bahasa hanya dengan mendengarkan radio. Anak memerlukan interaksi dengan lingkungan untuk mengumpulkan pengetahuan yang mereka perlukan Anak mempelajari sebuah bahasa dari fungsinya bukan bentuknya. Anak tidak menyadari betapa membingungkannya yang disebut tata bahasa itu, walaupun secara bertahap akan dipelajarinya. Dengan kata lain, anak dapat memahami serangkaian kalimat yang kompleks yang berada diatas levelnya dengan sederhana, lalu menyimpulkan apa inti atau maksud dari kalimat tersebut.

c. Anak tidak perlu diberitahu ketika melakukan sebuah kesalahan dalam berbahasa, karena anak mampu menyadarinya dan memperbaikinya sendiri. Namun, hal ini memerlukan waktu dalam prosesnya. Biarkan anak mendalami sendiri pengetahuan bahasa yang dia perlukan untuk memperbaiki kesalahannya. Apabila orang tua ingin membantu, cukup dengan memberikan contoh yang benar.

d. Anak mengimitasi cara berbahasa orang- orang yang paling dekat dan paling banyak berinteraksi dengannya. Dari situlah dialek diturunkan kepada anak. Dalam pembelajaran bahasa asing, anak mengimitasi pelafalan kata dengan lebih baik ketika memang sumber modelnya melafalkan kata-kata dengan baik.

Sejalan dengan O'grady, well (1999) menyatakan "It is not only the repetition of sounds they receive, instead, theydevelop rules and prove their assumptions to figure out for themselves." [itu bukan hanya sekedar pengulangan bunyi yang mereka terima, sebaliknya, mereka mengembangkan aturan dan 
membuktikan asumsi untuk memahaminya sendiri]. Donaldson (1978) dan Hughes (1986) juga menambahkan bahwa "They need to involve inhands-on experiences for effective learning." [Anak-anak perlu untuk terlibat secara langsung dalam suatu pengalaman untik belajar secara efektif. Pendek kata, karakteristik utama dalam proses pembelajaran anak adalah mendengarkan, mengimitasi, dan mengalami.

\section{Pembelajaran Bahasa Inggris Anak Usia Dini Berbasis Pemerolehan Bahasa Pertama}

Penelitian pertama yang melihat adanya peran yang sangat besar dalam proses pemerolehan bahasa pertama anak pada proses pembelajaran bahasa asing adalah Gouin (1880). Gouin (dalam Brown, 2008) percaya bahwa hal yang penting dalam pembelajaran bahasa adalah persoalan mengubah persepsi menjadi konsepsi. Maka, Gouin mulai merancang sebuah metode mengajar secara langsung (tanpa penerjemahan) dan secara konseptual (tanpa kaidah dan penjelasan gramatikal). Satu generasi kemudian, pemikiran awal Gouin ini kemudian ditindaklanjuti oleh Berlitz (dalam Brown 2007, p.25) yang memantapkan suatu metode yang dikenal sebagai Metode Langsung (Direct Method).Premis dasar metode Berlitz menyatakan bahwa pembelajaran bahasa kedua, khususnya pada anak, sebaiknya mengadaptasi proses pembelajaran bahasa pertama, yaitu dengan meperbanyak interaksi lisan aktif, penggunaan spontan bahasa, tanpa penerjemahan antara bahasa pertama dan kedua, dan sedikit sekali atau sama sekali tanpa analisis kaidah gramatikal. Berangkat dari berbagai teori dan hasil kajian mengenai proses pemerolehan bahasa dan pembelajaran bahasa pada anak, maka perumusan metode pembelajaran bahasa inggris pada anak sebaiknya mempertimbangkan aspek-aspek yang telah dibahas dalam kajian tersebut.Sesuai dengan pandangan kaum mentalis, rasionalis, dan nativis yang menyatakan bahwa LAD akan teraktivasi setelah mendapatkan paparan berupa input data bahasa, yaitu ketika anak mendengarkan bunyi bahasa, maka sebaiknya instruksi pembelajaran bahasa Inggris di kelas diberikan hanya dalam bahasa target.

Berdasarkan hal-hal tersebut di atas, maka dapat dirumuskan beberapa prinsip dalam pembelajaran bahasa Inggris berbasis proses pemerolehan bahasa pertama sebagai berikut: Mulailah dengan kalimat-kalimat perintah sederhana yang digunakan sehari-hari, seperti: Listen! Watch! Sit down! Be nice! Gunakan nada, ekspresi wajah, dan bahasa tubuh yang dapat membantu siswa untuk membuat asumsi awal mengenai makna dan arti ucapan tersebut. Perkenalkan kosa kata dengan menggunakannya dalamkalimatbahasa target untuk membangun konteks. Gunakan bahasa tubuh (gestur/ekspresi wajah) dan modifikasi penekanan atau intonasi untuk membantu anak memahami makna kosa kata yang 
menjadi fokus. Untuk mengawali, kenalkan anak pada lima kata kerja yang dekat dengan mereka seperti: eat, drink, want, watch, like. Lalu fokus menggunakan katakata tersebut dalam kalimat secara terus menerus dalam kurun waktu tertentu sampai anak dinilai telah menguasainya. Lalu, baru tambahkan lagi lima kata selanjutnya.

a. Ingat bahwa dalam pemerolehan bahasa, tahap awal pengenalan bahasa adalah proses imitasi, maka tata bahasa cukup diberikan dengan cara pemodelan dan pengucapan kata yang tepat merupakan keharusan, karena itu akan menjadi data penting bagi anak untuk tahap produksi bahasanya.

b. Hindari proses penerjemahan bahasa Inggris ke dalam bahasa Indonesia secara terus menerus. Sebaliknya, gunakan bahasa tubuh atau petunjuk lain di sekitar untuk membantu siswa memahami makna ucapan kita.

Selanjutnya, pandangan behaviorisme mengenai pemerolehan bahasa pada anak yang menyatakan bahwa pengembangan pengetahuan bahasa anak diperoleh dari rangsangan, respon, interaksi dan bantuan yang terjadi di dalam lingkungan, maka metode selanjutya yang dapat diadaptasi dari pandangan ini adalah sebagai berikut:

a. Perkenalkan ekspresi-eksperesi kalimat yang dibangun bertahap melalui interaksi dan tanpa menerjemahkannya. Sebagai contoh, ekspresi-ekspresi seperti: how are you? what's your name? thank you, i'm sorry diperkenalkan dalam satu kesatuan dengan ekspresi yang digunakan untuk responnya.

b. Gunakan media seperti gambar dan alat peraga lainnya hanya untuk pengenalan kosa kata konkrit. Penggunaan lingkungan sekitar sebagai media akan lebih baik dalam membangun konteks. Sehingga akan lebih memudahkan anak dalam menangkap konsepnya. Lalu gunakan dalam interaksi berupa percakapan ringan

\section{Simpulan}

Mengajarkan bahasa Inggris pada anak usia dini merupakan sebuah langkah yang tepat (lihat Stakanova dan Tolsikhina, 2014). Namun, anak-anak perlu dilihat sebagai individu yang berbeda dengan orang dewasa. Anak-anak dan orang dewasa mempelajari bahasa dengan cara yang berbeda (lihat O'Grady, 2007; Valipour dan Davatgari, 2014); dan bahkan dengan cara yang lebih cepat(lihat Santrock, 2007:313). Maka dari itu pembelajaran bahasa Inggris untuk anak- anak usia dini memerlukan perlakuan yang berbeda dibandingkan untuk orang dewasa. Seorang pengajar bahasa Inggris untuk anak usia dini perlu memahami bahwa seorang anak sejak lahir telah memiliki sejumlah kapasitas atau potensi bahasa 
yang akan berkembang sesuai dengan proses kematangan intelektualnya (lihat Brown, 1980). Seorang anak memiliki apa yang disebut dengan LAD (Language Acquisition Device) yang tidak dimiliki oleh orang dewasayang menjadi bekal bagi dirinya untuk memperoleh dan mengolah bahasa. Dengan LAD anak-anak akan mengembangkan aturan dan memahami bahasa dengan caranya (lihat Well, 1999). Oleh karena itu, tidak perlu untuk mengkotak-kotakan, mendikte apa yang seharusnya dipelajari oleh anak. Pembelajaran bahasa Inggris pada anak usia dini tidak boleh menghambat kreativitas dan imajinasi bahasa anak.

Karakteristik utama dalam proses pembelajaran bahasa pada anak adalah mendengarkan, mengimitasi, dan mengalami. Maka dari itu diperlukan suatu metode yang tepat untuk mengakomodir karakteristik tersebut. Metode pengajaran langsung (Direct Method) dipercaya masih relevan dan tepat untuk diterapkan dalam pengajaran bahasa Inggris untuk anak usia dini. Yakni metode mengajarsecara langsung (tanpa penerjemahan) dan secara konseptual (tanpa kaidah dan penjelasan gramatikal). Pada tataran teknisnya, guru harus memperbanyak interaksi lisan aktif, penggunaan spontan bahasa, tanpa penerjemahan antara bahasa pertama dan kedua, dan sedikit sekali atau sama sekali tanpa analisis kaidah gramatikal. Berdasarkan pemaparan sebelumnya maka dapat direkomendasikan hal-hal sebagai berikut:

1. Guru bahasa Inggris untuk usia dini agar lebih memahami dan mendalami karakter anak dan karakteristik pembelajaran bahasa pada anak. Dengan pemahaman dan pendalaman yang baik diharapkan guru dapat menggunakan kreativitasnya dalam mengajar sehingga proses pembelajaran menjadi lebih efektif dan tepat.

2. Implementasi metode langsung perlu dikembangkan lebih jauh dan rinci untuk mendapatkan ide-ide baru yang segar dan kreatif sehingga memperkaya khasanah pengajaran bahasa Inggris pada anak usia dini.

3. Efektivitas dari implementasi metode langsung yang dikembangkan juga perlu untuk dikaji lebih jauh secara empiris sehingga diharapkan akan memberikan manfaat pada dunia pengajaran bahasa Inggris untuk anak usia dini yang secara tidak langsung akan memberikan kontribusi pada percepatan pembangunan anak-anak Indonesia yang memiliki kecakapan berbahasa Inggris

\section{Daftar Rujukan}

Barbara, Thomson, PhD (1987). Language is Living: Aguide to Foster Language Development for mentally Retarted Individual. State of Wisconsin: United State office of Education 
Chomsky, Noam (2006). Language and Mind. United State Of America: Camdridge University Press.

Devinta P.S, dkk (2018) Mengajar Bahasa Inggris Anak Usia Dini. Malang Jawa Timur: UB Press

Ellis, Rod (1995) The Study of Second Languange Acquisition. Hongkong: Oxford University Press

Madyawati, Lilis . (2016) Strategi Pengembangan Bahasa Pada Anak. Jakarta : Kencana PT

Santrock, J. (2007). Adolesence” Fifth Edition. New York, NY: McGrawHill Company Inc. 